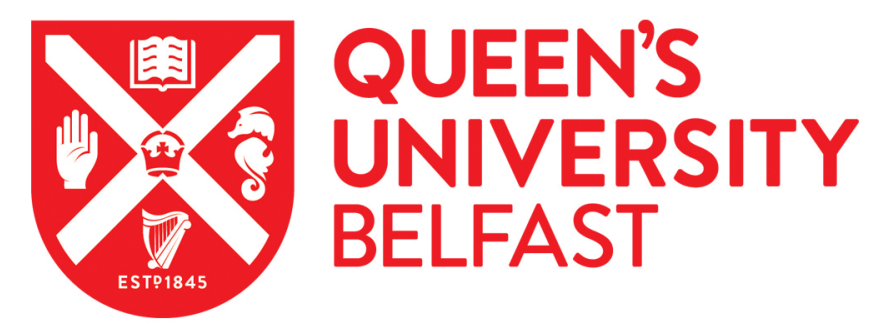

\title{
Friends of mine: an invasive freshwater mussel facilitates growth of invasive macrophytes and mediates their competitive interactions
}

\author{
Crane, K., Coughlan, N. E., Cuthbert, R. N., Dick, J. T. A., Kregting, L., Ricciardi, A., Maclsaac, H. J., \& Reid, N. \\ (2020). Friends of mine: an invasive freshwater mussel facilitates growth of invasive macrophytes and mediates \\ their competitive interactions. Freshwater Biology.
}

Published in:

Freshwater Biology

Document Version:

Peer reviewed version

Queen's University Belfast - Research Portal:

Link to publication record in Queen's University Belfast Research Portal

Publisher rights

(C) 2020 John Wiley \& Sons Ltd. This work is made available online in accordance with the publisher's policies. Please refer to any applicable terms of use of the publisher.

\section{General rights}

Copyright for the publications made accessible via the Queen's University Belfast Research Portal is retained by the author(s) and / or other copyright owners and it is a condition of accessing these publications that users recognise and abide by the legal requirements associated with these rights.

Take down policy

The Research Portal is Queen's institutional repository that provides access to Queen's research output. Every effort has been made to ensure that content in the Research Portal does not infringe any person's rights, or applicable UK laws. If you discover content in the Research Portal that you believe breaches copyright or violates any law, please contact openaccess@qub.ac.uk. 


\section{Friends of mine: an invasive freshwater mussel facilitates growth of invasive}

\section{2 macrophytes and mediates their competitive interactions}

3 Kate Crane ${ }^{1,2 *}$, Neil E. Coughlan ${ }^{1,2}$, Ross N. Cuthbert ${ }^{1,2}$, Jaimie T.A. Dick ${ }^{1,2}$, Louise

$4 \quad$ Kregting $^{2,3}$, Anthony Ricciardi ${ }^{4}$, Hugh J. MacIsaac ${ }^{5} \&$ Neil Reid $^{1,2}$

5

6 Institute for Global Food Security, School of Biological Sciences, Queen's University Belfast, 19 Chlorine

7 Gardens, Belfast BT9 5DL, Northern Ireland, UK

$8 \quad{ }^{2}$ Queen's University Marine Laboratory, 12-13 The Strand, Portaferry BT22 1PF, Northern Ireland, UK

$9{ }^{3}$ School of Natural and Built Environment, Queen's University Belfast, Stranmillis Road, Belfast BT9 5AG,

10 Northern Ireland, UK.

${ }^{4}$ Redpath Museum, McGill University, 859 Sherbrooke Street West, Montreal QC H3A 0C4, Canada

${ }^{5}$ Great Lakes Institute for Environmental Research, University of Windsor, Windsor ON N9B 3P4, Canada

* Corresponding author: kcrane02@qub.ac.uk

Author emails:

17 kcrane02@qub.ac.uk (KC)

18 neil.coughlan.zoology@gmail.com (NEC)

19 rcuthbert03@qub.ac.uk (RNC)

20 j.dick@qub.ac.uk (JTAD)

$21 \quad 1$.kregting@qub.ac.uk (LK)

22 tony.ricciardi@mcgill.ca (AR)

23 hughm@uwindsor.ca (HJM)

24 neil.reid@qub.ac.uk (NR)

\section{Keywords:}

27 Biotic resistance, facilitation, mutualism, biotic interactions, interspecific competition, invasional meltdown 


\section{Abstract}

1. Increasing rates of invasions in ecosystems worldwide necessitate experiments to determine the role of biotic interactions in the success and impact of multiple alien species. Here, we examined competitive and facilitative interactions among various combinations of three widespread and often co-occurring invaders: the zebra mussel Dreissena polymorpha, and the macrophytes Elodea canadensis and Elodea nuttallii.

2. Using a mesocosm-based, factorial experimental design, we assessed the effect of interspecific competition on macrophyte growth rates in the absence and presence at varying biomass of $D$. polymorpha.

3. Growth rates (wet grams day $^{-1}$ ) of E. canadensis and E. nuttallii were similar when grown in isolation. When grown together, in the absence of D. polymorpha, E. canadensis growth was not significantly reduced in the presence of $E$. nuttallii and vice versa. In the presence of $D$. polymorpha $(26.0 \pm 1 \mathrm{~mm})$, monocultural growth of $E$. canadensis was largely unaffected, while E. nuttallii growth was strongly enhanced. Low (2.64g) and medium (3.96g) mussel biomass led to negative interspecific effects between $E$. canadensis and E. nuttallii; at high (5.28g) mussel biomass, the effect of interspecific competition was negated.

4. Overall, D. polymorpha alleviated competitive interactions between the two invasive macrophytes when all three species co-occurred, and substantially enhanced growth of E. nuttallii with increasing mussel biomass, thereby suggesting a possible influence on the relative dominance of these macrophytes in the field.

5. Our study demonstrates how facilitations can cause shifts in dominance among closelyrelated invaders. The consequences of such facilitations for the structure and function of communities remain to be explored generally. 


\section{Introduction}

Despite burgeoning studies that demonstrate the influence of invasive alien species on ecosystems, community dynamics and native biodiversity, progress toward a predictive understanding of invader impact has been limited (Ricciardi et al. 2013; Dick et al. 2017). Globally, ecosystems are being invaded at accelerating rates, resulting in rapid accumulations of alien species (Ricciardi 2006; Ricciardi \& MacIsaac 2011; Seebens et al. 2017; Seebens et al. 2018) and increased opportunities for competitive and facilitative interactions that may generate variation in invader success and impact across space and time (Mony et al. 2007; Relva et al. 2010; Gallardo and Aldridge 2015; Meza-Lopez \& Siemann 2015; O'Loughlin \& Green 2017). Identification and quantification of these interactions across multiple contextdependencies is essential to developing effective management protocols (Ricciardi et al. 2013; Dick et al. 2017; Strayer et al. 2017).

Among the most complex context-dependencies are interspecific interactions of multiple invaders. Over the past two decades, studies have examined the community-level phenomenon of 'invasional meltdown', whereby facilitative interactions among invasive species promote their mutual establishment, persistence, and intensification of their impacts on recipient ecosystems (Simberloff \& Von Holle 1999; Ricciardi 2001; Simberloff 2006). A variety of studies have suggested that invasive species can singularly or synergistically modify recipient ecosystems in a manner that mediates the establishment and impact of additional invaders through, for example, habitat formation, enhanced foraging opportunities, provision of shelter, and displacement of predators (Adams et al. 2003; Green et al. 2011; Kobak et al. 2016; Sheppard et al. 2018). Several experimental studies have provided strong evidence of negative population-level impacts, amplified by facilitative interactions (e.g. Relva et al. 2010; Montgomery et al. 2011). However, these complex interactions are often poorly defined, equivocal, or underexplored, and typically overlooked in risk analysis and management 
strategies (Simberloff 2006; Roy et al. 2014; Gallardo \& Aldridge 2015; O’Loughlin \& Green 2017). For example, there may be many instances where an invader can facilitate some resident species while inhibiting others within the invaded community (Ricciardi 2001; Ward \& Ricciardi 2007, 2013; Relva et al. 2010; Montgomery et al. 2011), and such differential effects could have significant impacts on the structure and functional ecology of the community (O’Dowd et al. 2003; Green et al. 2011; Montgomery et al. 2011). Interspecific competition between plant species, whereby one species constrains or interferes with the ability of others to acquire resources, is a common determinant of invader success (Gioria \& Osborne 2014; Ellawala \& Kodithuwakku 2017; Paolacci et al. 2018a,b) and is often related to differential tolerance to resource scarcity or asymmetries in resource acquisition (Mony et al. 2007; Paolacci et al. 2016; Ellawala \& Kodithuwakku 2017). Opportunistic use of available nutrients can result in a competitive advantage and enhanced growth (Dawson et al. 2011; Paolacci et al. 2016), in accordance with theory that predicts a higher Relative Growth Rate (RGR) in successful invaders compared to competitors (Funk \& Vitousek 2007). Moreover, under nutrient enriched conditions, some plants may rapidly outcompete co-occurring species. Exploitation of differential niches within the same environment can ensure improved access to resources, and a competitive advantage over species unable to exploit multiple niches (Evans and Edwards 2001). On the other hand, ecological or phylogenetic similarity between existing and new invaders (as found within the same genus) can facilitate invader success, perhaps owing to direct facilitation or weaker competitive interactions (Sheppard et al. 2018), although even congeneric species can display differential RGRs under the same environmental conditions (Paolacci et al. 2016, 2018a). Accordingly, examination of how both native and invasive species exploit resources for rapid growth will enhance understanding of invasion dynamics (Paolacci et al. 2018b); however, 
there is a paucity of studies that examine competitive interactions between multiple invaders, especially plants (Kuebbing et al. 2013; Sheppard et al. 2018).

Elodea canadensis Rich. In Michx. (1803) and Elodea nuttallii (Planch) H. St. John, 1920 are congeneric aquatic macrophytes native to North America (Barrat-Segretain et al. 2002; Vernon \& Hamilton 2011) and invasive in Europe, Asia and Australasia. Both species were likely initially introduced through the aquarium and ornamental trades. These rooted, submerged, perennial species typically inhabit lakes, ponds and slow-moving rivers (BarratSegretain et al. 2002; Champion et al. 2010). Both Elodea spp. increase flood risk, devalue adjacent property, disrupt navigation, confound water extraction, and impede irrigation and recreational activities (Hussner et al. 2017). Although non-native, since first being recorded present in 1836, E. canadensis had become widespread in both Britain and Ireland prior to the introduction of E. nuttallii in 1966 (Simpson 1984). However, E. nuttallii can rapidly dominate invaded ecosystems and significantly alter freshwater communities (Champion et al. 2010; Zehnsdorf et al. 2015; Thouvenot \& Thiébaut 2018; but see Kelly et al. 2015). Following its establishment, E. nuttallii has often been observed to displace E. canadensis (Simpson 1990). Although the displacement of E. canadensis by E. nuttallii is not readily explained by most physiological parameters, it appears that under resource-enriched conditions the ability of $E$. nuttallii to accumulate phosphorus is greater than that of the former (Robach et al. 1995; BarratSegretain et al. 2002; Josefsson 2011). Equally, comparative elongation of E. nuttallii stems may give it a competitive advantage in canopy formation, thus shading and inhibiting $E$. canadensis growth (Kelly et al. 2015).

The zebra mussel Dreissena polymorpha (Pallas, 1771), native to the Black and Caspian sea basins, is a prolific invasive bivalve that can dominate freshwater ecosystems and cause myriad ecological and economic impacts (Ricciardi et al. 1998; Higgins \& Vander Zanden 2010; Ward \& Ricciardi 2013; Sousa et al. 2014). In particular, D. polymorpha has displaced native mussel 
species, increased water clarity, altered nutrient cycling, and caused shifts in macrophyte assemblages and blooms of filamentous macroalgae (Ricciardi et al. 1998; Rosell et al. 1999; Ricciardi 2003; Ward \& Ricciardi 2013). Possible mutualistic interactions between $D$. polymorpha and invasive macrophytes, such as Myriophyllum spicatum and Potamogeton crispus, have been observed (MacIsaac 1996; Skubinna et al. 1995), as have a range of commensalistic interactions whereby $D$. polymorpha promotes establishment and persistence of a variety of invaders (Bially and MacIsaac 2000; Ricciardi 2001). In essence, D. polymorpha appears to be disproportionately involved in facilitative interactions with other invaders (DeVanna et al. 2011). Therefore, Dreissena could potentially alter competitive interactions between congeneric invasive Elodea species. Notably, the displacement of E. canadensis by $E$. nuttallii has been observed to occur more rapidly in areas containing relatively high $D$. polymorpha densities (KC pers. obs.). Although some juvenile D. polymorpha can be found adhering to plant leaves and stems, the majority of the mussels reside on the benthic substrate. Hence, we propose that the presence of $D$. polymorpha can accelerate the competitive replacement of $E$. canadensis by $E$. nuttallii, likely through the latter's more efficient use of available nutrient resources excreted by $D$. polymorpha.

We thus used laboratory-based mesocosm experiments to examine the effect of interspecific competition - and the role of $D$. polymorpha in mediating such competition - on the growth rates of E. canadensis and E. nuttallii. As dead mussel shells adsorb phosphate (Xiong et al. 2011), the impact of non-living mussel shells on plant growth was also considered. We therefore tested the effect of the presence of non-living zebra mussel shells and varied living mussel densities on the growth rates of each Elodea species when grown alone (single species) and together (both species experiencing interspecific competition). Based on field observations and pilot studies (Crane, 2019), we hypothesised that: 1) E. nuttallii would have a higher growth rate than E. canadensis; 2) interspecific competition will reduce growth rates of both 
species, especially negatively affecting E. canadensis growth; and that 3 ) D. polymorpha would facilitate enhanced Elodea spp. growth, especially for E. nuttallii, principally through favourable changes in habitat conditions including water chemistry parameters.

\section{Methods}

\subsection{Specimen collection}

Elodea canadensis was collected from Tully Mill Lough $\left(54^{\circ} 15^{\prime} 32.1^{\prime \prime} \mathrm{N} ; 7^{\circ} 42^{\prime} 50.4^{\prime \prime} \mathrm{W}\right)$ in August 2017. Elodea nuttallii was collected from Lough Erne, Northern Ireland (54¹8'12.1"N; $7^{\circ} 37^{\prime} 20.8^{\prime \prime}$ ) in August 2017. Lough Erne is a naturally eutrophic lake and its water chemistry reflects the underlying geology of limestone and sandstone which gives rise to carbonate-rich, slightly acidic waters. Strands of each species were cut just above the level of the roots and were transported in source water to Queen's Marine Laboratory (QML), School of Biological Sciences, Queen's University Belfast, Portaferry, Northern Ireland, UK. In addition, 80 L of lake water was collected from Lough Erne at the same time. This water was later used for mesocosm experiments.

Dreissena polymorpha was collected from Lough Erne, Northern Ireland (54 $17^{\prime} 07.89^{\prime \prime} \mathrm{N}$ $\left.7^{\circ} 32^{\prime} 52.61^{\prime \prime} \mathrm{W}\right)$ in August 2017. Mussels were detached from rocky substrates by clipping byssal threads and transported in a cooler filled with source lake water. Only large adult mussels with a shell length 24-30mm were selected and placed into an aerated 20-L tank for 48 hours.

All plant and mussel specimens were housed in aerated aquaria filled with source water, maintained at a constant temperature of $12^{\circ} \mathrm{C}$. Source water for experimental use was kept aerated and likewise maintained under laboratory conditions. Organisms were acclimated for a minimum of 48 hours prior to experimental use. 


\subsection{Experimental design}

Plant fragments were randomly selected from holding aquaria and apical fragments were cut to a length of $60 \mathrm{~mm}$. Specimens were cut immediately below the final node 16 hours prior to the start of the experiment and washed in dechlorinated tap water to remove any debris. In all cases, apical fragments were harvested from mature plants. Where possible, fragments were cut from unbranched sections of stem; however, if present, axillary side shoots were removed. Excess liquid was gently removed by manually spinning individual fragments in a handheld centrifuge (Westmark), ten times clockwise followed by ten spins counter-clockwise. Fragment wet weight (mg) was recorded using a Mettler Toledo AB104. The base of each individual fragment was protected using a small piece of cotton wool before being wrapped with a $60 \times$ $5 \mathrm{~mm}$ lead weight to keep the base of the fragment at the bottom of the mesocosm and the apical section positioned vertically.

Naturally occurring wild densities of $D$. polymorpha were estimated as living population biomass (soft and hard tissues; wet weight $\mathrm{g} \mathrm{m}^{-2}$ ) at ten locations in Lough Erne. For the experimental treatments, three relative biomass categories were used: low $\left(300 \mathrm{~g} \mathrm{~m}^{-2}\right)$, medium $\left(450 \mathrm{~g} \mathrm{~m}^{-2}\right)$ and high $\left(600 \mathrm{~g} \mathrm{~m}^{-2}\right)$. Biomass estimates for $D$. polymorpha were similar to those reported for Dreissena spp. inhabiting lakes in North America and Europe (Custer \& Custer 1993; Cleven \& Frenzel 1993; Karatayev et al. 2014; Ginn et al. 2017). In Lake Erie, for example, the average biomass for mixed populations of D. polymorpha and a functionally similar congener bivalve, the quagga mussel D. rostriformis bugensis, ranged from (mean \pm SE) $55.4 \pm 11.8$ to $588.8 \pm 94.4 \mathrm{~g} \mathrm{~m}^{-2}$ amongst different sites (Karatayev et al. 2014). However, biomass is highly variable in relation to stage of invasion or age of population, and can be impacted by changes to biotic and abiotic conditions (see Karatayev et al. 2014).

In addition, the biomass of non-living $D$. polymorpha shells was recorded with shells being collected and scraped as clean as possible from each site (Table 1). Mean biomass of dead 
shells was then calculated from across all sites, and a representative biomass was selected (100g $\mathrm{m}^{-2}$ ). Mesocosms (1.5L: high-density polyethene) had a surface area of $88 \mathrm{~cm}^{2}$, thus mussel treatments were scaled to replicate naturally occurring biomass i.e. zero mussels (representing their absence), dead shells (0.88 g; an entire adult mussel $26.0 \pm 1 \mathrm{~mm}$, scraped clean), Low (2.64g; 1 adult mussel $26.0 \pm 1 \mathrm{~mm})$, Medium (3.96g; 2 adult mussels $26.0 \pm 1 \mathrm{~mm}$ ) and High (5.28g; 3 adult mussels $26.0 \pm 1 \mathrm{~mm}$ ) densities (Table 1). Mussels were placed directly on the base of the mesocosms, but were free to reposition themselves within the mesocosm at all times. Mesocosms did not contain any additional substrate.

Elodea fragments were placed in the mesocosms which acted as a proxy for a shallow lake ecosystem. As above, lake water obtained from Lough Erne was used to ensure plants had sufficient nutrients for growth and D. polymorpha had sufficient seston to filter feed (Vanderploeg 2017). Each mesocosm had two individual growing strands of Elodea; either comprising a single species (i.e. two strands of E. canadensis or two strands of E. nuttallii), representing the absence of interspecific competition; or both species together (i.e. one strand of E. canadensis with one strand of E. nuttallii), representing the presence of interspecific competition. These were combined in a factorial design with mussel treatments (zero, shells only, low, medium and high density). Control mesocosms of water only were also used, i.e. no plants or mussels added. Mesocosm water was exchanged for fresh, aerated lake water every three days to ensure $D$. polymorpha had sufficient food, whilst air lines delivered oxygen and water motion for the duration of the experiment. In total, the experiment was conducted over twelve days, with four water cycles lasting three days each (see below). All experimental groups were replicated in triplicate. Light of $30 \mu \mathrm{mol}$ photons $\mathrm{m}^{-2} \mathrm{~s}^{-1}$ was supplied by four 52 W Arcadia 1200mm Marine Stretch LED lamps under a 16:8 hour light: dark regime; 30 $\mu \mathrm{mol}$ photons was considered sufficient for photosynthesis (Mielecki \& Pieczyńska 2005). All waste invasive plant material was destroyed after the experiment by autoclaving. 


\subsection{Plant growth rates}

Elodea biomass increase or growth rate (GR) was estimated following Van Echelpoel (2016):

$$
G R=\frac{(f W W-i W W)}{t}
$$

where $f \mathrm{WW}=$ final wet weight $(\mathrm{g}), i \mathrm{WW}=$ initial wet weight and $t=$ time interval.

\subsection{Water chemistry parameters}

Dissolved oxygen $\left(\mathrm{mg} \mathrm{L}^{-1}\right), \mathrm{pH}$ (pH Units), Total Dissolved Solids $\left(\mathrm{mg} \mathrm{L}^{-1}\right)$, temperature $\left({ }^{\circ} \mathrm{C}\right)$ 556 MPS multi-parameter field meter. Water samples were taken from the source water prior to every water change, and from each mesocosm at the end of each 3-day water cycle. These samples were tested for nitrate $\left(\mu \mathrm{mol} \mathrm{L} \mathrm{L}^{-1}\right)$, nitrite $\left(\mu \mathrm{mol} \mathrm{L} \mathrm{L}^{-1}\right)$, ammonium $\left(\mu \mathrm{mol} \mathrm{L} \mathrm{L}^{-1}\right)$ and phosphate $\left(\mu \mathrm{mol} \mathrm{L}{ }^{-1}\right)$ using a Bran+Luebbe AutoAnalyser 3. Samples were taken by syringe

with each syringe rinsed with $18 \Omega$ high purity water twice between samples to avoid contamination. A total of four water replacements were carried out throughout the course of the experiment.

For each mesocosm, nutrient change was established in relation to the difference in nutrient concentrations between both the immediate beginning and end of each 3-day water cycle. In all cases, due to inherent minor fluctuations of probe readings, a mean value of five consecutive measurements was obtained from each mesocosm for every sampling point. Overall nutrient flux throughout the lifetime of the experiment was determined as the mean of nutrient changes across all 3-day water cycles. Overall, initial nutrient concentrations of the lake water used to 
replenish each mesocosm every three days were (mean $\pm \mathrm{SE}$ ): phosphate, $1.2 \pm 0.1$; nitrate, 5.3 \pm 0.5 ; nitrite, $1.0 \pm 0.1$; ammonium, $5.2 \pm 0.4\left(\mu \mathrm{mol} \mathrm{L}{ }^{-1}\right)$.

\subsection{Statistical Analyses}

257

The frequency distribution of macrophyte growth rate (the dependent variable in all tests) was assessed using a Kolmogorov-Smirnov test and was not significantly different from a normal distribution $(K S=0.075, p=0.200)$, thus parametric tests were used for analyses. The experimental design focused on key questions, principally: is growth of one invasive plant influenced by the presence of another, and does a third invader facilitate or inhibit the interaction of the first two? Thus, our statistical approach focused on answering these specific and allied questions by utilising pairwise comparisons or comparisons of specific treatment groups. A single global model including all main effects and possible interactions was initially constructed, but its complexity and the nuance of its interpretation detracted from the clear messages that emerged from a simpler statistical approach. Thus, pairwise comparisons between any two experimental treatment groups were tested using $t$-tests, whilst comparisons across multiple groups i.e. three or more experimental treatments were tested using one-way Analysis of Variance (ANOVA). The effect of interspecific competition $(0 / 1=$ absent or present), mussel treatment (none, shells only, low, medium and high density), and their interaction term, on Elodea growth rates was tested using a two-way ANOVA.

Water nutrient flux was examined separately for nitrate, nitrite, ammonium and phosphate by examining Plant and Mussel treatments and their interaction using a two-way ANOVA. Least Significant Difference (LSD) post-hoc tests between treatment levels was used to identify pairwise effects. All statistical analyses were performed using IBM SPSS v25. 


\section{Results}

In the absence of $D$. polymorpha, the growth rates of $E$. canadensis (mean \pm SE: $0.012 \pm 0.003$ wet $\left.\mathrm{g} \mathrm{day}^{-1}\right)$ and E. nuttallii $\left(0.011 \pm 0.001\right.$ wet $\left.\mathrm{g} \mathrm{day}^{-1}\right)$ did not differ when grown in monocultures $\left(t_{\mathrm{df}=10}=0.378, \mathrm{p}=0.714 ;\right.$ Fig. 1a). Further, E. canadensis growth was not reduced in the presence of E. nuttallii (Fig 1b), and vice versa (Fig. 1c). In the presence of non-living mussel shells, monoculture growth of $E$. canadensis was significantly reduced $\left(t_{\mathrm{df}=10}=2.227\right.$, p=0.050; Fig. 1d), whereas that of E. nuttallii was unaffected (Fig. 1e). When grown together in the presence of mussel shells, growth rates of both plants did not differ (Fig. 1b \& 1c).

Elodea canadensis growth was unaffected by D. polymorpha biomass in the absence of interspecific competition (Fig. 1f), but was reduced by the presence of E. nuttallii $\left(F_{\mathrm{df}=1,21}=15.031, p=0.001\right.$; Fig. $\left.1 \mathrm{~g}\right)$; the impact of interspecific competition was dependent on mussel biomass $\left(F_{\mathrm{df}=2,21}=12.173, p<0.001\right.$; Fig. 1h). Specifically, interspecific competition reduced E. canadensis growth most at low mussel biomass and to a lesser degree at medium mussel biomass. The facilitating effect of D. polymorpha on E. canadensis growth at high mussel biomass was only strong enough to negate the negative effect of interspecific competition with E. nuttallii, such that growth of E. canadensis $\left(0.012 \pm 0.003\right.$ wet $\left.\mathrm{g} \mathrm{day}^{-1}\right)$ precisely equalled that when it was grown in isolation without either species (Fig. 1i). Thus, $D$. polymorpha had a compensatory effect restoring E. canadensis growth otherwise lost due to interspecific competition with $E$. nuttallii.

In contrast, in the absence of interspecific competition with E. canadensis, E. nuttallii growth was strongly enhanced by greater $D$. polymorpha biomass $\left(F_{\mathrm{df}=2,21}=18.158, p<0.001\right.$; Fig. 1j). Conversely, when mussels are present, E. nuttallii growth was negatively affected by interspecific competition with E. canadensis $\left(F_{\mathrm{df}=1,21}=45.010, p<0.001\right.$; Fig. $\left.1 \mathrm{k}\right)$. However, growth of E. nuttallii did not differ with, and was independent of, mussel biomass (Fig. 11). Similar to that observed for E. canadensis, high D. polymorpha biomass had a compensatory 
effect that negated growth inhibition caused by interspecific competition on E. nuttallii (Fig. $1 \mathrm{~m})$.

Water chemistry parameters remained consistent throughout the experiment with mean \pm SE values for dissolved oxygen $13.2 \pm 0.32 \mathrm{mg} \mathrm{L}^{-1}, \mathrm{pH} 7.35 \pm 0.01$, Total Dissolved Solids $0.15 \pm 0.003 \mathrm{mg} \mathrm{L}^{-1}$, temperature $12.4 \pm 0.02{ }^{\circ} \mathrm{C}$ and Conductivity $175.1 \pm 0.3 \mu \mathrm{S} \mathrm{cm}^{-1}$. Nitrate, nitrite and phosphate values differed significantly between plant treatments (Table 2), and were elevated in the presence of Elodea (Fig. 2a-c). Ammonium and phosphate also differed significantly between mussel treatments (Table 2). Ammonium was depressed in the presence of dead mussel shells only (Fig. 2d), whilst phosphate was depressed only at medium and high mussel densities (Fig. 2e). There was no significant interaction between Plant*Mussel treatments on any water chemistry parameters (Table 2 ).

\section{Discussion}

In the absence of $D$. polymorpha, although plant growth tended to be more reduced in Elodea occurring Elodea spp., negative effects were not evident at a high mussel biomass. The facilitation of an invader by the presence of another is consistent with invasional meltdown, even though in this case one invader was promoted over another. Further, a reduction of interspecific competition between two invasive species by the presence of an additional third invader is also consistent with the concept of invasional meltdown. In the present study, these effects were associated with significant shifts in nutrient concentrations. Baseline nutrient levels of the lake water used to replenish the mesocosms tended to increase over time, which likely reflects some die-off of phytoplankton inhabiting the water. However, baseline nutrient 
levels are within the average range documented for Lough Erne by the Northern Ireland Environment Agency over a nine-year survey (2006-2014, corresponding to mean values of 6.5, 1.1, 2.8 and $0.6 \mu \mathrm{mol} \mathrm{L} \mathrm{L}^{-1}$ for nitrate, nitrite, ammonium and phosphate respectively (Crane 2019).

Previous experiments have compared the growth rates of E. canadensis and E. nuttallii in monoculture and sympatry (e.g. Barrat-Segretain \& Arnaud 2004). Equally, the ability of $D$. polymorpha to engineer the invaded environment has been shown by several studies (Arnott \& Vanni 1996; MacIsaac 1996; Ricciardi \& MacIsaac 2000; Karatayev et al. 2002; Ricciardi 2003; Bykova et al. 2006; Higgins et al. 2008; Higgins \& Vander Zanden 2010; Nogaro \& Steinman, 2014). However, this study is the first to demonstrate the potential for competitive and facilitative interactions among these three invaders. Not only does the presence of $D$. polymorpha facilitate the growth rate of E. nuttallii, but it also reduced competition between E. canadensis and E. nuttallii. Moreover, field observations of juvenile D. polymorpha attached to E. nuttallii is suggestive of a mutualistic relationship (KC pers. obs.), consistent with reports of colonization of macrophytes by D. polymorpha (MacIsaac 1996; Horvath \& Lamberti 1997; Bodamer \& Ostrovsky 2010). Mussels attached to drifting E. nuttallii could also benefit from local dispersal (cf. Horvath \& Lamberti 1997) or be transported overland attached to macrophytes snagged on recreational boat trailers (Johnson et al. 2001). Although small fragmentary propagules of Elodea can produce new growth, fragments tend to not to survive extended periods of air exposure, e.g. $<3$ hours at $20^{\circ} \mathrm{C}$ (Coughlan et al. 2018). Nevertheless, rapid spread and establishment of $E$. nuttallii continues to have detrimental knock-on effects on native biota, especially plants, invertebrates and algal periphyton (Kelly et al. 2015). Overall, our results corroborate the role of D. polymorpha as an ecological engineer, with broad influence on community dynamics and an ability to mediate interactions among invasive species (Ricciardi 2001; DeVanna et al. 2011). Our results also highlight the need for improved 
spread-prevention and population suppression methods for these damaging invaders (Crane et al. 2019; Cuthbert et al. 2019).

Dreissena polymorpha can enhance nutrient cycling through excretion and, on a lake-wide basis, large populations can: 1) excrete significant concentrations of ammonia, nitrate and dissolved phosphorus; 2) reduce concentrations of suspended seston, chlorophyll a, phytoplankton and total phosphorus; 3) alter the structure and metabolic function of the benthic bacterial community; and 4) increase water transparency (Gardner et al. 1995; James et al. 1997; Gardner et al. 2001; Matthews \& Effler 2001; Lohner et al. 2007; Higgins et al. 2008). A significant effect of zebra mussel metabolism is their ability to convert particulate forms of nutrients into dissolved, available forms (Arnott \& Vanni 1996). Although not statistically evident, our results suggest a trend of greater ammonium depletion by higher mussel densities when Elodea was present, and while Elodea can utilize both nitrate and ammonium the nutrient of preference is ammonium (Ozimek et al. 1993). No significant depletion of nitrate or nitrite was observed during the experimental period when plants were present. However, interestingly, increasing density of living D. polymorpha was associated with declining phosphate concentrations. Although dead mussel shells adsorb phosphate (Xiong et al. 2011), this was demonstrably not the case in the present study. While nutrients were unlikely to be limiting, our results suggest that differences in growth rate could be attributed to plant competition or the presence of D. polymorpha, and that further work is required to specifically test the role of how both Elodea species nutrients excreted by Dreissena and why phosphate levels declined with increasing mussel biomass.

Given that regeneration of E. nuttallii is higher than E. canadensis in the spring, and the latter is thought to have a weaker ability to compete for light (Barrat-Segretain \& Elger 2004), the former may have a competitive advantage where the species co-occur (Barrat-Segretain et al. 2002). Szabó et al. (2018) found that increasing levels of light and nitrogen elicited 
phenotypic responses such as stem elongation in E. nuttallii that were far greater than that of E. canadensis. They also found that under eutrophic conditions, E. nuttallii branched rapidly and reached the surface sooner than E. canadensis, thereby shading out the weaker invader and other aquatic plants. These factors could partly explain the displacement of E. canadensis via increased canopy formation and the eventual shading of the less vigorous species. Additionally, the ability of $D$. polymorpha to excrete available forms of nutrients, required in differing amounts by Elodea spp. for growth, may also help explain the increased growth of E. nuttallii when occurring in the absence of intraspecific competition. Similarly, the functionally similar congener D. rostriformis bugensis and E. nuttallii are hypothesized to be mutually facilitative in a German lake in which mussel filtration apparently caused an increase in water clarity, whilst macrophytes provided substrate for attachment of juvenile mussels and may have prevented summer hypoxia (Wegner et al. 2019).

Based on their current distribution, rate of spread, and history of successful establishment, interactions between these three invasive species are likely to occur with increasing frequency. Our findings suggest that dense D. polymorpha populations strongly facilitate the growth of $E$. nuttallii, but not $E$. canadensis, perhaps promoting the dominance of the former over the latter where they co-occur. This could be interpreted as a form of invasional meltdown, in which the dominance of one invader is favoured over another (e.g. Ricciardi 2001; O'Dowd et al. 2003; Montgomery et al. 2011). We expect such complex facilitative/antagonistic interactions to be common in ecosystems that are increasingly invaded.

\section{Acknowledgments}

KC was supported through contributions from Queen's University Belfast, the University of Windsor, McGill University and Waterways Ireland. NEC and JTAD are supported by the Irish EPA research grant 2015-NC-MS-4. RNC acknowledges support from Department for the 
403 Economy (DfE), Northern Ireland. AR and HJM acknowledge support from NSERC Canada.

404 We particularly thank Dr Patrick Joyce, Dr Lawrence Eagling, Simon Exley, Emma Healey, 405 James Dickey and Maurice Collins for their helpful contributions. Thanks are also due to the 406 Natural Environment Research Council (NERC). We also thank two anonymous reviewers and 407 the editorial team for helpful comments.

408

\section{Author contributions}

410

$\mathrm{KC}$ and $\mathrm{AR}$ proposed the study; $\mathrm{KC}$ designed the experiment; $\mathrm{KC}$ conducted the experiment; $\mathrm{KC}$ and LK performed chemical analysis; KC and NR performed data analysis; all authors contributed to writing the manuscript, which was jointly led by $\mathrm{KC}$ and $\mathrm{NEC}$, and gave final approval for publication.

\section{Data Accessibility}

Data will be made available following acceptance for publication in Dryad digital repository.

\section{References}

Adams, M. J., Pearl, C.A. \& Bury, R.B. (2003) Indirect facilitation of an anuran invasion by non-native fishes. Ecology Letters, 6, 343-351.

Arnott, D. \& Vanni, M.J. (1996) Nitrogen and phosphorus cycling by the zebra mussel (Dreissena polymorpha) in the western basin of Lake Erie. Canadian Journal of Fisheries and Aquatic Sciences, 53, 646-659.

Barrat-Segretain M.H., Elger A., Sagnes P. \& Puijalon S. (2002) Comparison of three life history traits of invasive Elodea canadensis Michx. and Elodea nuttallii (Planch.) H. St. John. Aquatic Botany, 74, 299-313. 
Barrat-Segretain M.H. \& Elger A. (2004) Experiments on growth interactions between two invasive macrophyte species. Journal of Vegetation Science, 15, 109-114.

Barrat-Segretain M.H. \& Arnaud E. (2004) Experiments on growth interactions between two invasive macrophyte species. Journal of Vegetation Science, 15, 109-114.

Bially A. \& MacIsaac H.J. (2000) Fouling mussels (Dreissena) colonize soft sediments in Lake Erie and facilitate benthic invertebrates. Freshwater Biology, 43, 85-98.

Bodamer B.L. \& Ostrofsky M.L. (2010) The use of aquatic plants by populations of the zebra mussel (Dreissena polymorpha) (Bivalvia: Dreissenidae) in a small glacial lake. Nautilus, 124, 100-106.

Bykova O., Laursen A., Bostan V., Bautista J. \&McCarthy L. (2006) Do zebra mussels (Dreissena polymorpha) alter lake water chemistry in a way that favours Microcystis growth? Science of the Total Environment, 371, 362-372.

Champion P.D., Clayton J.S. \& Hofstra D.E. (2010) Nipping aquatic plant invasion in the bud: weed risk assessment and the trade. Hydrobiologia, 656, 167-172.

Cleven E.J., Frenzel P. (1993) Population-dynamics and production of Dreissena polymorpha (Pallas) in River Seerhein, the outlet of Lake Constance (Obersee). Archiv fur Hydrobiologie, 127, 395-407

Coughlan NE, Cuthbert RN, Kelly TC, Jansen MAK (2018) Parched plants: survival and viability of invasive aquatic macrophytes following exposure to various desiccation regimes. Aquatic Botany, 150, 9-15.

Crane K. (2019) Aquatic invasive alien species: identification, distribution, impact, control and biosecurity. PhD thesis, Queen's University Belfast. 
Crane K, Cuthbert RN, Dick JTA, Kregting L, MacIsaac HJ, Coughlan NE (2019) Full steam ahead: direct steam exposure to inhibit spread of invasive aquatic macrophytes. Biological Invasions, 21, 1311-1321.

Custer C.M., Custer T.W. (1997) Occurrence of zebra mussels in near-shore areas of western Lake Erie. Journal of Great Lakes Research 23, 108-115.

Cuthbert RN, Crane K, Dick JTA, Caffrey JM, MacIsaac HJ, Coughlan NE (2019) Die Hard: survival and viability of invasive Elodea nuttallii following submergence in aquatic disinfectants. Aquatic Botany, 154, $11-17$.

Dawson W., Fischer M. \& van Kleunen M. (2011) The maximum relative growth rate of common UK plant species is positively associated with their global invasiveness. Global Ecology and Biogeography, 20, 299-306.

DeVanna K.M., Bodamer B.L., Wellington C.G., Hammer E., Mayer C.M., \& Bossenbroek, J.M. (2011) An alternative hypothesis to invasional meltdown in the Laurentian Great Lakes region: general facilitation by Dreissena. Journal of Great Lakes Research, 37, $632-641$.

Dick J.T.A., Laverty C., Lennon J.J., Barrios-O’Neill D., Mensink P.J., Britton J.R. \& Caffrey J.M. (2017) Invader Relative Impact Potential: a new metric to understand and predict the ecological impacts of existing, emerging and future invasive alien species. Journal of Applied Ecology, doi:10.1111/1365-2664.12849.

Ellawala C. \& Kodithuwakku K.H. (2017) Effect of interspecific competition on the growth and nutrient uptake of three macrophytes in nutrient-rich water. Aquatic Ecology, 51, $10.1007 / \mathrm{s} 10452-017-9640-5$. 
Evans J.R. \& Edwards E. (2001) Nutrient uptake and use in plant growth. Pages 75-81 In Proceedings or net ecosystem exchange CRC workshop (Kirschbaum, M.U.F, and Mueller, R., eds), Cooperative Research Centre for Greenhouse Accounting, Canberra.

Funk J.L. \& Vitousek P.M. (2007) Resource-use efficiency and plant invasion in low-resource systems. Nature, 446, 1079-1081.

Gallardo B. \& Aldridge D.C. (2015) Is Great Britain heading for a Ponto-Caspian invasional meltdown? Journal of Applied Ecology, 52, 41-49.

Gardner W.S., Cavaletto J.F., Johengen T.H., Johnson J.R., Heath R.T. \& Cotner Jr., J.B. (1995) Effects of the zebra mussel, Dreissena polymorpha, on community nitrogen dynamics in Saginaw Bay, Lake Huron. Journal of Great Lakes Research, 21, 529544.

Gardner W.S., Yang L., Cotner J.B., Johengen T.H. \& Lavrentyev P.J. (2001) Nitrogen dynamics in sandy freshwater sediments (Saginaw Bay, Lake Huron). Journal of Great Lakes Research, 27, 84-97.

Ginn B.K., Bolton R, Coulombe D., Fleischaker T., Yerex G. (2017) Quantifying a shift in benthic dominance from zebra (Dreissena polymorpha) to quagga (Dreissena rostriformis bugensis) mussels in a large, inland lake. Journal of Great Lakes Research, 44, 271-182.

Gioria M. \& Osborne B.A. (2014) Resource competition in plant invasions: emerging patterns and research needs. Frontiers in Plant Science, 5, 1-21.

Green P.T., O’Dowd D.J., Abbott K.L., Jeffery M., Retallick K. \& Mac Nally R. (2011) Invasional meltdown: Invader-invader mutualism facilitates a secondary invasion. Ecology, 92, 1758-1768. 
Higgins T.M., Grennan J.M. \& McCarthy T.K. (2008) Effects of recent zebra mussel invasion on water chemistry and phytoplankton production in a small Irish lake. Aquatic Invasions, 3, 14-20.

Higgins S.N. \& Vander Zanden M.J. (2010), What a difference a species makes: a metaanalysis of dreissenid mussel impacts on freshwater ecosystems. Ecological Monographs, 80, 179-196.

Horvath T.G. \& Lamberti G.A. (1997) Drifting macrophytes as a mechanism for zebra mussel (Dreissena polymorpha) invasion of lake-outlet streams. American Midland Naturalist, $138,29-36$.

Hussner A., Stiers I., Verhofstad M.J.J.M., Bakker E.S., Grutters B.M.C., Haury J., van Valkenburg J.L.C.H., Brundu G., Newman J., Clayton J.S., Anderson L.W.J. \& Hofstra D. (2017) Management and control methods of invasive alien aquatic plants: a review. Aquatic Botany, 136, 112-137.

James W.F., Barko J.W. \& Eakin H.L. (1997) Nutrient regeneration by the zebra mussel (Dreissena polymorpha). Journal of Freshwater Ecology, 12, 209-216, DOI: 10.1080/02705060.1997.9663528.

Johnson L.E., Ricciardi A., \& Carlton J.T. (2001) Overland dispersal of aquatic invasive species: a risk assessment of transient recreational boating. Ecological Applications, 11, 1789-1799.

Josefsson M. (2011) NOBANIS - Invasive Species Fact Sheet - Elodea canadensis, Elodea nuttallii and Elodea callitrichoides - From: Online Database of the European Network on Invasive Alien Species - NOBANIS www.nobanis.org, Date of access 12/3/2017. 
516 Karatayev A., Burlakova L.E. \& Padilla D.K. (2002) Impacts of zebra mussels on aquatic communities and their role as ecosystem engineers. Invasive Aquatic Species of Europe, 433-446.

Karatayev A.Y., Burlakova L.E., Pennuto C., Ciborowskide J., Karatayev V.A., Juette P., Clapsadl M. (2014) Twenty five years of changes in Dreissena spp. populations in Lake Erie. Journal of Great Lakes Research, 40, 550-559

Kobak J., Poznańska M., Jermacz Ł., Kakareko T., Prądzynski D., Łodygowska M., Montowska K. \& Bącela-Spychalska K. (2016) Zebra mussel beds: an effective feeding ground for Ponto-Caspian gobies or suitable shelter for their prey? PeerJ, 2016;4:e2672 doi: $10.7717 /$ peerj.2672.

Kuebbing S. E., Nuñez M. A. \& Simberloff D. (2013) Current mismatch between research and conservation efforts: the need to study co-occurring invasive plant species. Biological Conservation, 160, 121-129. https://doi.org/10.1016/j.biocon.2013.01.009

MacIsaac H.J. (1996) Potential abiotic and biotic impacts of zebra mussels on the inland waters of North America. American Zoologist, 36, 287-299.

Matthews D.A. \& Effler S.W. (2001) Water quality signatures and the zebra mussel invasion. Clearwaters, Spring, 31, No. 1.

Meza-Lopez M.M. \& Siemann E. (2015) Experimental test of the Invasional Meltdown Hypothesis: an exotic herbivore facilitates an exotic plant, but the plant does not reciprocally facilitate the herbivore. Freshwater Biology, 60, 1475-1482. 
Mielecki M. \& Pieczyńska E. (2005) The influence of Fragmentation on the growth of Elodea canadensis Michx. in different light conditions. Polish Journal of Ecology, 53, 155164.

Montgomery W.I., Lundy M.G. \& Reid N. (2011) 'Invasional meltdown': evidence for unexpected consequences and cumulative impacts of multispecies invasions. Biological Invasions, 6,111-1125.

Mony C., Koschnick T.J., Haller W.T. \& Muller S. (2007) Competition between two invasive Hydrocharitaceae (Hydrilla verticillata (L.f.) (Royle) and Egeria densa (Planch)) as influenced by sediment fertility and season. Aquatic Botany, 86, 236-242.

Nogaro G. \& Steinman A.D. (2014) Influence of ecosystem engineers on ecosystem processes is mediated by lake sediment properties. Oikos, 123, 500-512.

O’Dowd D.J., Green P.T. \& Lake P.S. (2003) Invasional 'meltdown' on an oceanic island. Ecology Letters, 6, 812-817.

O'Loughlin L.S. \& Green P.T. (2017) Secondary invasion: When invasion success is contingent on other invaders altering the properties of recipient ecosystems. Ecology and Evolution, 7, 7628-7637.

Ozimek T., Van Donk E. \& Gulati R.D. (1993) Growth and nutrient uptake by two species of Elodea in experimental conditions and their role in nutrient accumulation in a macrophyte dominated lake. Hydrobiologia, 251, 13-18.

Paolacci S., Harrison S. \& Jansen M.A.K. (2016) A comparative study of the nutrient responses of the invasive duckweed Lemna minuta, and the native, co-generic species Lemna minor. Aquatic Botany, 134, 47-53. 
Paolacci S., Harrison S. \& Jansen M.A.K. (2018a) The invasive duckweed Lemna minuta Kunth displays a different light utilisation strategy than native Lemna minor Linnaeus. Aquatic Botany, 146, 8-14.

Paolacci S., Jansen M.A.K. \& Harrison S. (2018b) Competition between Lemna minuta, Lemna minor, and Azolla filiculoides. growing fast or being steadfast? Frontiers in Chemistry, $6,1-15$.

Relva M.A., Nuñez M.A. \& Simberloff D. (2010) Introduced deer reduce native plant cover and facilitate invasion of non-native tree species: evidence for invasional meltdown. Biological Invasions, 12, 303-311.

Ricciardi A. \& MacIsaac H.J. (2011) Impacts of Biological Invasions on Freshwater Ecosystems. In: Fifty Years of Invasion Ecology: The Legacy of Charles Elton, 1st edition. Edited by David M. Richardson. Chapter 16: 212-224.

Ricciardi A., Neves R.J. \& Rasmussen J.B. (1998) Impending extinctions of North American freshwater mussels (Unionoida) following the zebra mussel (Dreissena polymorpha) invasion. Journal of Animal Ecology, 67, 613-619.

Ricciardi A. (2001) Facilitative interactions among aquatic invaders: is an "invasional meltdown" occurring in the Great Lakes? Canadian Journal of Fisheries and Aquatic Sciences, 58, 2513-2525.

Ricciardi A. (2003) Predicting the impacts of an introduced species from its invasion history: an empirical approach applied to zebra mussel invasions. Freshwater Biology, 48, 972981.

Ricciardi A. (2006) Are modern biological invasions an unprecedented form of global change? Conservation Biology, 21, 329-336. 
Ricciardi A., Hoopes M.F., Marchetti M.P. \& Lockwood J.L. (2013) Progress toward understanding the ecological impacts of non-native species. Ecological Monographs, $83,263-282$.

Robach F., Hajnsek I., Eglin I. \& Trémolières M. (1995) Phosphorus sources for aquatic macrophytes in running waters: water or sediment?, Acta Botanica Gallica: Botany Letters 142(6): 719-731, DOI:10.1080/12538078.1995.10515296.

Rosell R.S., Maguire C.M. \& McCarthy T.K. (1999) First reported settlement of zebra mussels Dreissena polymorpha in the Erne system, Co. Fermanagh, Northern Ireland. Biology and Environment, 98, 191-193.

Roy H.E., Peyton J., Aldridge D.C., Bantock T., Blackburn T.M., Britton R., Clark P., Cook E., Dehnen-Schmutz K., Dines T., Dobson M., Edwards F., Harrower C., Harvey M.C., Minchin D., Noble D.G., Parrott D., Pocock M.J.O., Preston C.D., Roy S., Salisbury A., Schönrogge K., Sewell J., Shaw R.H., Stebbing P., Stewart A.J.A. \& Walker K.J. (2014) Horizon scanning for invasive alien species with the potential to threaten biodiversity in Great Britain. Global Change Biology, 20, 3859-3871.

Seebens H., Blackburn T.M., Dyer E.E., Genovesi P., Hulme P.E., Jeschke J.M., Pagad S., Pyšek P., Winter M., Arianoutsou M., Bacher S., Blasius B., Brundu G., Capinha C., Celesti-Grapow L., Dawson W., Dullinger S., Fuentes N., Jäger H., Kartesz J., Kenis M., Kreft H., Kühn I., Lenzner B., Liebhold A., Mosena A., Moser D., Nishino M., Pearman D., Pergl J., Rabitsch W., Rojas-Sandoval J., Roques A., Rorke A., Rossinelli S., Roy H.E., Scalera R., Schindler S., Štajerová K., Tokarska-Guzik B., van Kleunen M., Walker K., Weigelt P., Yamanaka T. \& Essl F. (2017) No saturation in the accumulation of alien species worldwide. Nature Communications, 8, 1-9. 
Seebens H., Blackburn T.M., Dyer E.E., Genovesi P., Hulme P.E., Jeschke J.M., Pagad S., Pysek P., van Kleunen M., Winter M., Ansong M., Arianoutsou M., Bacher S., Blasius B., Brockerhoff E.G., Brundu G., Capinha C., Causton C.E., Celesti-Grapow L., Dawson W., Dullinger S., Economo E.P., Fuentes N., Guénard B., Jäger H., Kartesz J., Kenis M., Kühn I., Lenzner B., Liebhold A.M., Mosena A., Moser D., Nentwig W., Nishino M., Pearman D., Pergl J., Rabitsch W., Rojas-Sandoval J., Roques A., Rorke S., Rossinelli S., Roy H.E., Scalera R., Schindler S., Stajerová K., Tokarska-Guzik B., Walker K., Ward D.F., Yamanaka T. \& Essl F. (2018) Global rise in emerging alien species results from increased accessibility of new source pools. Proceedings of the National Academy of Sciences of the United States of America, 115:E2264-E2273.

Sheppard C.S., Carboni M., Essl F., Seebens H., DivGrass Consortium \& Thuiller W. (2018) It takes one to know one: Similarity to resident alien species increases establishment success of new invaders. Diversity and Distributions, 24, 680-691.

Simberloff D. \& Von Holle B. (1999) Positive interactions of nonindigenous species: invasional meltdown? Biological Invasions, 1, 21-32.

Simberloff D. (2006) Invasional meltdown 6 years later: important phenomenon, unfortunate metaphor, or both? Ecology Letters, 9, 912-919.

Simpson D.A. (1984) A short history of the introduction and spread of Elodea Michx in the British Isles. Watsonia, 15, 1-9.

Simpson D.A. (1990) Displacement of Elodea canadensis Michx by Elodea nuttallii (Planch.) H. St. John in the British Isles. Watsonia, 18, 173-177.

Skubinna J.P., Coon T.G. \& Batterson T.R. (1995) Increased abundance and depth of submersed macrophytes in response to decreased turbidity in Saginaw Bay, Michigan. Journal of Great Lakes Research, 21, 476-488. 
Sousa R., Novais A. \& Strayer D.L. (2014) Invasive bivalves in fresh waters: impacts from individuals to ecosystems and possible control strategies. Hydrobiologia, 735, 231251.

Strayer D.L., Caraco N.F., Cole J.J., Findlay S. \& Pace M.L. (1999) Transformation of freshwater ecosystems by bivalves: A case study of zebra mussels in the Hudson River. BioScience, 49, 19-27.

Strayer D.L., D’Antonio C.M., Essl F., Fowler M.S., Geist J., Hilt S., Jaric I., Jöhnk K., Jones C.G., Lambin X., Latzka A.W., Pergl J., Pysek P., Robertson P., von Schmalensee M., Stefansson R.A., Wright J. \& Jeschke J.M. (2017) Boom-bust dynamics in biological invasions: towards an improved application of the concept. Ecology Letters, 20, 13371350.

Szabó S., Peeters E.T.H.M., Várbíró G., Borics G. \& Lukács, B.A. (2018) Phenotypic plasticity as a clue for invasion success of the submerged aquatic plant Elodea nuttallii. Plant Biology, 21, 54-63.

Thouvenot L. \& Thiébaut G. (2018) Regeneration and colonization abilities of the invasive species Elodea canadensis and Elodea nuttallii under a salt gradient: implications for freshwater invisibility. Hydrobiologia, 817, 193-203.

Vanderploeg H.A., Sarnelle O., Liebig J.R., Morehead N.R., Robinson S.D., Johengen T. \& Horst G.P. (2017) Seston quality drives feeding, stoichiometry and excretion of zebra mussels. Freshwater Biology, 62, 664-680.

Van Echelpoel W., Boets P. \& Goethals P.L.M. (2016) Functional Response (FR) and Relative Growth Rate (RGR) do not show the known invasiveness of Lemna minuta (Kunth). PLoS ONE, 11(11): e0166132. doi:10.1371/journal. pone.0166132. 
Vernon E. \& Hamilton H. (2011) Literature review on methods of control and eradication of Canadian pondweed and Nuttall's pondweed in standing waters. Scottish Natural Heritage Commissioned Report No. 433.

Ward J.M. \& Ricciardi A. (2007) Impacts of Dreissena invasions on benthic macroinvertebrate communities: a meta-analysis. Diversity and Distributions, 13, 155-165.

Ward J.M. \& Ricciardi A. (2013) Impacts of Dreissena on benthic macroinvertebrate communities: predictable patterns revealed by invasion history. In: Nalepa, T. F., Schloesser, D.W. (Eds.), Quagga and Zebra Mussels: Biology, Impacts, and Control, 2nd edition CRC Press, Boca Raton, FL: 599-610.

Wegner B., Kronsbein A.L, Gillefalk M., van de Weyer K., Kohler J., Funke E., Monaghan M.T., Hilt S (2019) Mutual facilitation among invading Nuttall's Waterweed and Quagga Mussels. Frontiers in Plant Science 10, art. 789.

Xiong J., Qin, Y., Islam, E., Yue, M., Wang, W. (2011) Phosphate removal from solution using powdered freshwater mussel shells. Desalination 276, 317-321.

Zehnsdorf A., Hussner A., Eismann F., Helmut Rönicke H. \& Melzer A. (2015) Management options of invasive Elodea nuttallii and Elodea canadensis. Limnologica, 51, 110-117. 
Table 1 Mussel treatments with corresponding field and mesocosm mussel densities, specimen count and total biomass.

\begin{tabular}{|c|c|c|c|}
\hline Mussel treatment & $\begin{array}{c}\text { Field \& mesocosm } \\
\text { biomass }\left(\mathrm{g} \cdot \mathrm{m}^{-2}\right)\end{array}$ & $\begin{array}{l}\text { No. of specimens } \\
\text { in mesocosms (n) }\end{array}$ & $\begin{array}{c}\text { Total specimen } \\
\text { biomass (g) }\end{array}$ \\
\hline None (control) & 0 & 0 & 0.00 \\
\hline Shells only & 100 & 1 & 0.88 \\
\hline Low & 300 & 1 & 2.64 \\
\hline Medium & 450 & 2 & 3.96 \\
\hline High & 600 & 3 & 5.28 \\
\hline
\end{tabular}


i) Elodea canadensis

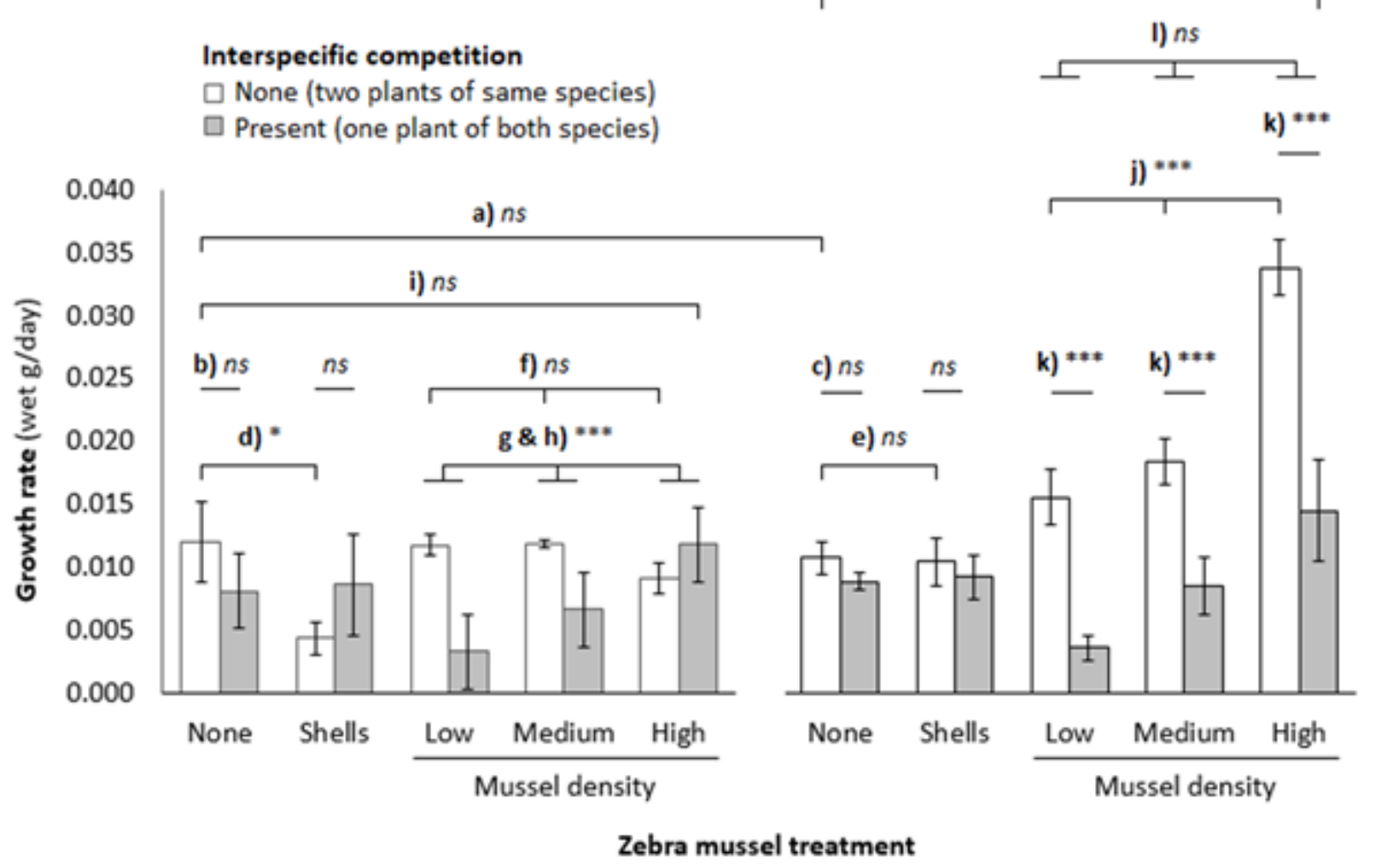

Fig. 1 Mean ( \pm SE) comparative growth rates (wet g.day ${ }^{-1}$ ) for i) Elodea canadensis (left panel) and ii) Elodea nuttallii (right panel) with (grey bars) and without (white bars) the presence of interspecific competition (paired bars) in each zebra mussel, Dreissena polymorpha, treatment category ( $x$-axis). Horizontal lines above bars show significance testing between selected pairs or groups of categories indicated by the span of the bars (individually cited a-m in Results text). $n s=p>0.05, *=p<0.05, * *=p<0.01$ and $* * *=p<0.001$. 
Table 2 Two-way ANOVA fitting the effect of Plant and Mussel treatments and their interaction term for a) nitrate, b) nitrite, c) ammonium and d) phosphate.

\begin{tabular}{|c|c|c|c|c|}
\hline $\begin{array}{l}\text { Dependent variable } \\
\text { Independent variables }\end{array}$ & $\boldsymbol{F}$ & n.df. & d.df. & $p$ \\
\hline \multicolumn{5}{|c|}{ a) Nitrate $\left(F_{\mathrm{df}=19,40}=1.905, p=0.043, \mathrm{r}^{2}=0.475\right)$} \\
\hline Plant & 5.243 & 3 & 40 & 0.004 \\
\hline Mussel & 1.331 & 4 & 40 & 0.275 \\
\hline Plant*Mussel & 1.261 & 12 & 40 & 0.278 \\
\hline \multicolumn{5}{|c|}{ b) Nitrite $\left(F_{\mathrm{df}=19,40}=1.919, p=0.041, \mathrm{r}^{2}=0.309\right)$} \\
\hline Plant & 6.262 & 3 & 40 & 0.001 \\
\hline Mussel & 0.134 & 4 & 40 & 0.969 \\
\hline Plant*Mussel & 1.429 & 12 & 40 & 0.193 \\
\hline \multicolumn{5}{|c|}{ c) Ammonium $\left(F_{\mathrm{df}=19,40}=2.558, p=0.006, \mathrm{r}^{2}=0.549\right)$} \\
\hline Plant & 1.706 & 3 & 40 & 0.181 \\
\hline Mussel & 6.187 & 4 & 40 & 0.001 \\
\hline Plant*Mussel & 1.562 & 12 & 40 & 0.143 \\
\hline \multicolumn{5}{|c|}{ d) Phosphate $\left(F_{\mathrm{df}=19,40}=6.018, p<0.001, \mathrm{r}^{2}=0.741\right)$} \\
\hline Plant & 3.948 & 3 & 40 & 0.015 \\
\hline Mussel & 20.417 & 4 & 40 & $<0.001$ \\
\hline Plant*Mussel & 1.735 & 12 & 40 & 0.095 \\
\hline
\end{tabular}


a)

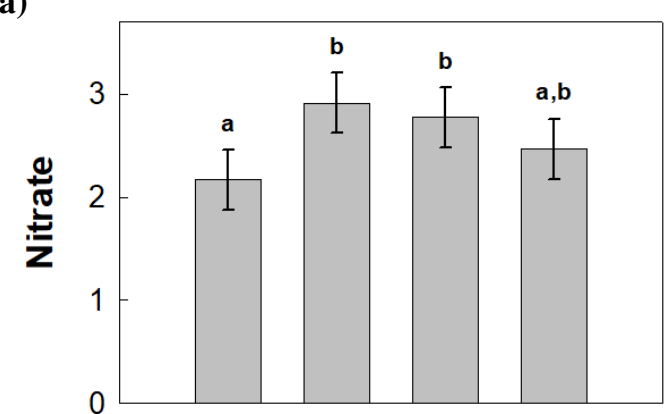

b)

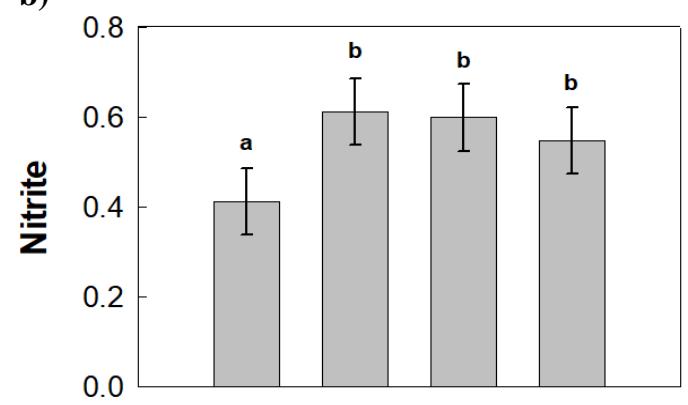

c)

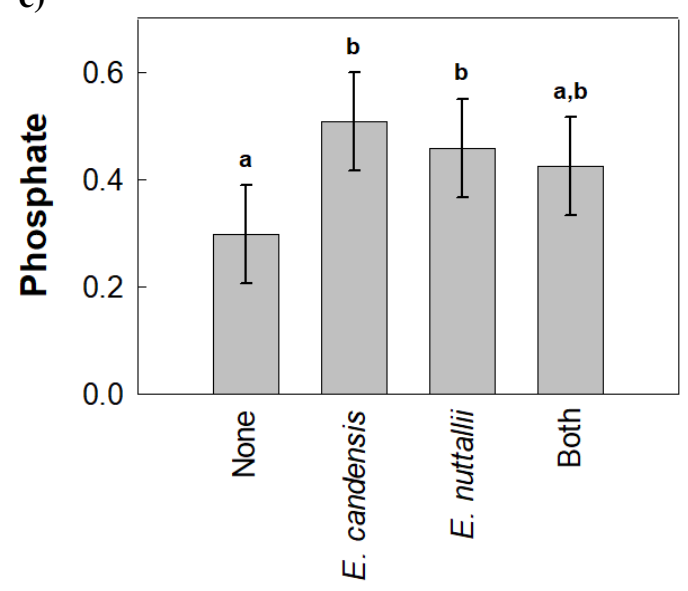

d)

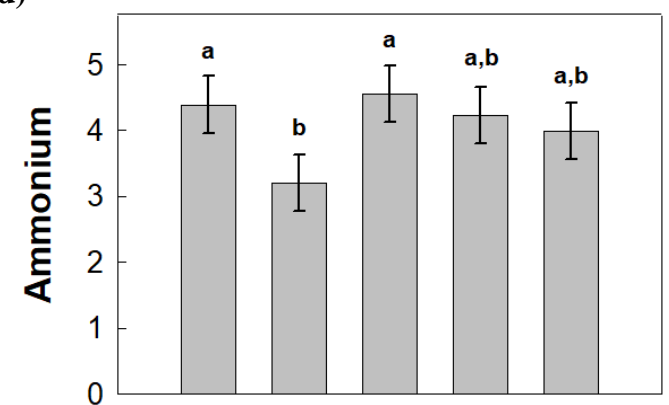

e)

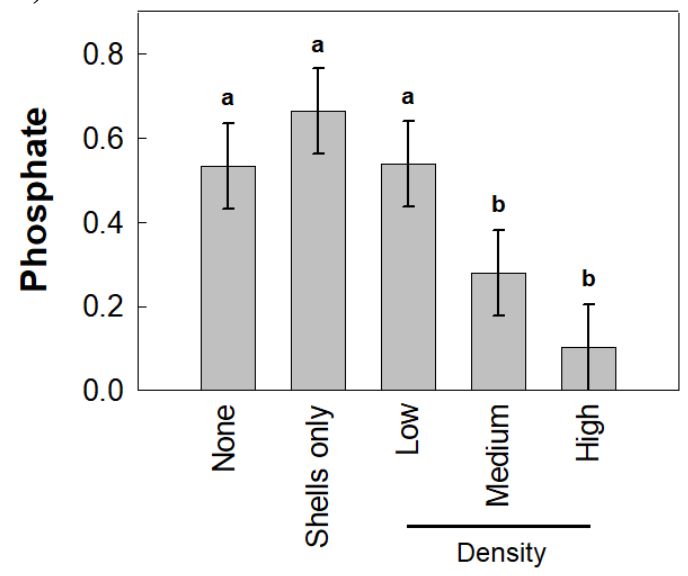

Mussel treatment
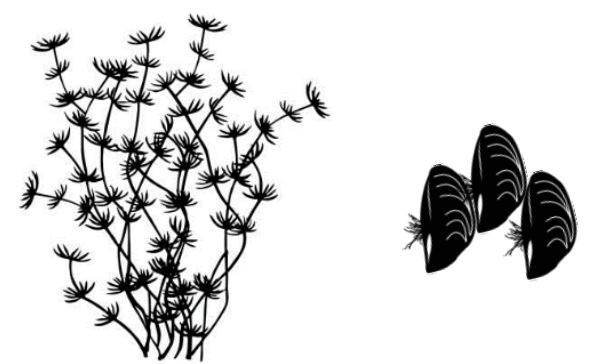

Plant treatment

Fig. 2 Significant effects highlighted from Table 2. Mean $\pm 95 \%$ CIs $\left(\mu \mathrm{mol} \mathrm{L}^{-1}\right)$ for a) nitrate, b) nitrite and c) phosphate showing the effect of plant treatments (right column) and d) ammonium and e) phosphate showing the effect of mussel treatments (left column). Least Significant Difference (LSD) post-hoc tests are shown above the bars; treatment with different letters were significantly different $(p<0.05)$. Drawings not to scale. 